\title{
Carbon stock potential of scattered trees on farmland along an altitudinal gradient in Tigray, Northern Ethiopia
}

\author{
Yikunoamlak Gebrewahid ${ }^{1 *}$ (D) Tewolde-Berhan Gebre-Egziabhier ${ }^{3}$, Kassa Teka ${ }^{2}$ and Emiru Birhane ${ }^{2,4}$
}

\begin{abstract}
Introduction: Trees on agricultural landscape play a vital role in ecosystem services including food security that supports human livelihood. They can further offer synergy between adaptation and mitigation in addressing climate change impact. Understanding aboveground tree biomass and soil organic carbon stocks along the altitudinal gradient provide opportunities for better management of the carbon pools. However, little is known on how altitudinal gradient influences on carbon stock of woody biomass and soil of scattered trees on farmland, particularly in a dry area.

Methods: The study area were stratified in to five class (500-1000, 1000-1500, 1500-2000, 2000-2500, and 2500-3000 m a.s.l). Quadrats (100 m ×50 m) were randomly selected from each of stratified altitudinal gradients. At every sampling point, one composite soil sample was taken at $60 \mathrm{~cm}$ soil depth for soil organic carbon analysis. For the purpose of woody biomass estimation, allometric equations developed for a similar area were used. Finally, aboveground biomass carbon (AGC), belowground biomass carbon (BGC), soil organic carbon (SOC), and total carbon stock (TC) status were estimated and variables were compared using one-way analysis of variance (ANOVA).

Results: The result indicated that AGC, BGC, SOC, and TC varied significantly $(p<0.05)$ along with an altitudinal gradient. The upper altitude (2500-3000 m a.s.l) AGC, BGC, SOC, and TC stock was estimated as $17.97 \mathrm{Mg} \mathrm{C} \mathrm{ha}^{-1}, 6.53 \mathrm{Mg} \mathrm{Cha}^{-1}$, 23.09 Mg C ha ${ }^{-1}, 47.59 \mathrm{Mg} \mathrm{C} \mathrm{ha}^{-1}$ respectively, and significantly higher than the other altitudinal gradient.

Conclusions: We conclude that scattered trees on farmland hold a high potential of carbon storage which may greatly contribute to the climate resilience green economy strategy and their conservation should be promoted.
\end{abstract}

Keywords: Aboveground biomass carbon, Belowground biomass carbon, Soil organic carbon, Total carbon stock

\section{Introduction}

Tree cover on agricultural landscape is variable globally. The tree cover is $10 \%, 20 \%$, and $50 \%$ in the $46 \%, 27 \%$, and $7.5 \%$ cover of cultivated land respectively (Zomer et al. 2009). Trees are an essential part and a common feature of many agricultural landscapes, where they provide a range of ecosystem services that support livelihoods. In Ethiopia, these scattered trees occurred in different land use systems such as in the communal land, coffee plantations, crop fields, and along roadsides (Teklay 2005). Some of these trees were left when the natural

\footnotetext{
*Correspondence: yikuno22@gmail.com; yikuno22@yahoo.com ${ }^{1}$ Humera Agricultural Research Center (HuARC), Tigray Agricultural Research Institute (TARI), P.O. Box 62, Humera, Ethiopia

Full list of author information is available at the end of the article
}

forest was converted to other land use system; others regenerated after the land was cleared or were actively planted by farmers. For example, parkland agroforestry in the farmland of Northern Ethiopia often contain a local momona species (Faidherbia albida (Del.) A. Chev.) because farmers plant or maintain this species to provide soil quality and productivity (Teklay 2005).

Farmers are growing and maintain trees on their agricultural land for different variety of products and services (Kuyah et al. 2016), and manage a mix of exotic and indigenous trees in different ways (Nyaga et al. 2015). The major productive services of trees such as lumber, plywood, fuelwood, or charcoal come from the wood of trees (Young 1997), food, medicines, feed/fodder for livestock, and natural gums (Kuyah et al. 2016). 
The major protective or ecosystem services of trees on farmlands are to the harbor for birds and insects (Scherr and McNeely 2008), improve soil fertility, and serve to conserve soil and water (Barrios et al. 2012).

Tree on the agricultural landscape is also important in enhancing farmers' adaptive capacity and reducing the susceptibility of farming systems to climate change impacts (Boye and Albrecht 2005). In addition, trees provide a wide range of environmental benefits such as control of erosion and storing a significant amount of carbon on both above and below ground in the form of soil organic carbon. Therefore, trees on farmland must be included in the climate change programs and policies such as Reducing Emissions from Deforestation and Forest Degradation (REDD+). However, the potential of trees on farmlands to sequester carbon depends upon the woody species composition, ages of trees, geographic location, agroecological conditions (climate, altitude, and wind), management regimes, and soil characteristics (Bunker et al. 2005; Henry et al. 2009; Newaj et al. 2016).

Most studies indicated that even if trees on farmland or agricultural landscape are not primarily designed to sequester carbon, it is a unique opportunity to increase carbon stocks in the terrestrial biosphere (Albrecht and Kandji 2003). Tree on farmland contains less carbon than primary or managed forests but they contain significantly higher carbon stocks than annual crops (Henry et al. 2009). Studies suggested that the integration and proper management of trees on farmland has a great potential to sequester carbon from the atmosphere, in addition, to rehabilitate degraded land and to improve the livelihood of the rural communities. However, altitudinal gradients are among the most powerful "natural experiments" for testing ecological responses of biota to environmental changes (Körner 2007). Similarly, Leuschner et al. (2007) and Zhu et al. (2010) reported that altitude has a significant influence on biomass and soil carbon stock potential of these tree on farmland.

The study aimed to quantify and compare the woody biomass carbon and soil organic carbon potential of trees on farmland along an altitudinal gradient. This study focuses on two related questions: (1) is there any significant variation in above- and belowground biomass carbon stocks along with an altitudinal gradient of scattered trees on farmlands? (2) Is there any significant variation in soil organic carbon stock along with an altitudinal gradient of scattered trees on farmlands of the Western Zone Tigray, Ethiopia?

\section{Materials and method}

Study area description

The study was carried out in the Western administrative zone of the Tigray region, Northern Ethiopia $\left(13^{\circ} 42^{\prime}\right.$ to $14^{\circ} 28^{\prime}$ North Latitude and $36^{\circ} 23^{\prime}$ to $37^{\circ} 31^{\prime}$ East Longitude) (Fig. 1). The study site is comprised of trees on the agricultural landscape that occupies lower, middle, and upper altitude gradients. Lowland is categorized into two zones namely 500-1000 m a.s.l and 1000-1500 m

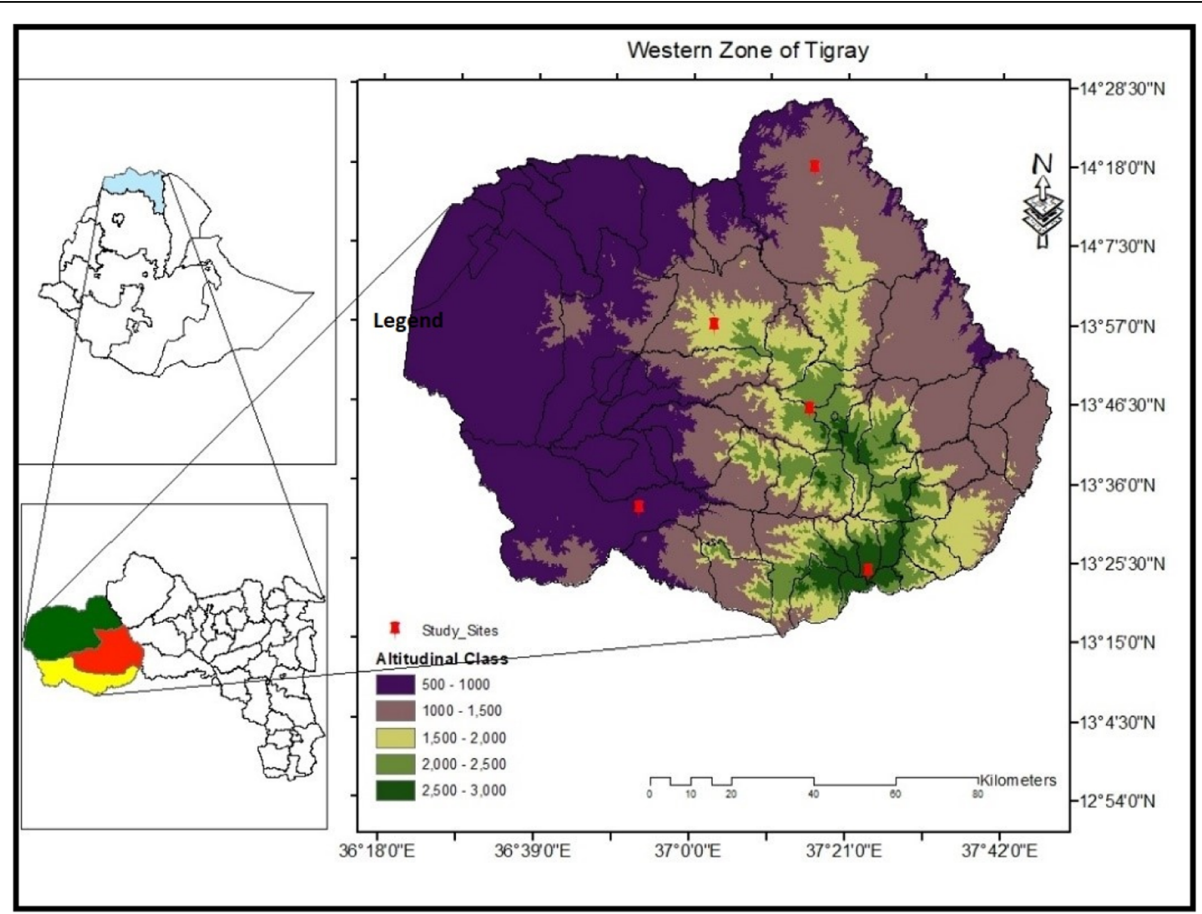

Fig. 1 Map of altitudinal classifications of the Western Zone of Tigray, Northern Ethiopia 
a.s.l, middle land is categorized into two zones namely 1500-2000 m a.s.l and 2000-2500 m a.s.l, and upper latitude is categorized into one zone namely 2500$3000 \mathrm{~m}$ a.s.l. The total land area of the western zone of Tigray is 1.5 million ha. The western zone of Tigray is one of the less densely populated areas in Ethiopia, with an average density of 33 person $\mathrm{km}^{-2}$. The elevation ranges from 500 to $3000 \mathrm{~m}$ a.s.l. and the annual rainfall for the zone ranges from 609 to $2316 \mathrm{~mm}$ and mean annual temperature ranges ( $\min$ and max) from 27 to $45^{\circ}$ $\mathrm{C}$ and 10 to $22^{\circ} \mathrm{C}$. A range of soil types are found, but the dominant soil types are Vertisols, Luvisols, and Cambisols. The farming is carried out to meet household needs and to derive cash. Mechanized agriculture is practised in the lower altitude. The dominant farming is a mixed crop-livestock farming system solely managed by family labor. The total cultivated area is 573,285 ha (38.2\%) (Table 1).

\section{Data collection method Sampling design}

The study site was stratified into the following altitudinal gradients: $500-1000 \mathrm{~m}, 1000-1500 \mathrm{~m}, 1500-2000 \mathrm{~m}$, 2000-2500 m, and 2500-3000 m above sea level based on the Ethiopian Agroecological (Hurni 1998) Zones. The Advanced Spaceborne Thermal Emission and Reflection Radiometer Digital Elevation Model (ASTER-DEM), $30 \times$ $30 \mathrm{~m}$ resolution supported by global positioning system (GPS) points were used to classify the gradient. The classification was done in Arc GIS Version 10 software.

\section{Sampling techniques and field measurement}

Inventory of scattered tree on farmlands was conducted from randomly selected rectangular seventy-five (75) plot of $100 \mathrm{~m} \times 50 \mathrm{~m}$ (Nikiema 2005) along five altitudinal gradients. Rectangular plots were chosen as they tend to include more of the within-plot heterogeneity and more representative than square or circular plots of the same area (Hairiah et al. 2001). Trees and/or shrubs $\geq 5 \mathrm{~cm}$ in DBH, DSH, and height were measured using a diameter tape, diameter caliper (Ponce-Hernandez et al. 2004), and Suunto hypsometer respectively. Woody plants which have multiple stems above $1.3 \mathrm{~m}$ height were considered as a single plant and woody plants with multiple stems or fork below $1.3 \mathrm{~m}$ height were measured each individual stem. Plant identification was done in the field using their local name and useful trees and shrubs for Ethiopia (Bekele-Tesemma and Tengnäs 2007) and Eritrea (Bein et al. 1996).

Soil samples were taken from four corners and center of the 0.5 ha rectangular plot using " $\mathrm{X}$ " pattern at a $60 \mathrm{~cm}$ soil depth (Negash and Starr 2015) and composited to make one representative sample for each quadrant for analysis of soil organic carbon. In addition, from the same quadrant, soil samples for soil bulk density determination were collected using $10 \mathrm{~cm}$ length and $3.4 \mathrm{~cm}$ diameter core sampler carefully driven into the soil to avoid compaction (Roshetko et al. 2002). In total, 75 disturbed soil samples and 375 non-disturbed soil samples were taken using auger and core sampler.

\section{Data analysis \\ Aboveground carbon stock estimation}

Biomass carbon stocks for each plot $\left(\mathrm{Mg} \mathrm{C} \mathrm{ha}^{-1}\right)$ were calculated as the product of dry matter biomass and carbon content. Trees and shrub plant biomass were calculated using the plot inventory data and allometric biomass functions. The allometric equation developed

Table 1 Characteristics of the five altitudinal gradients of the studied scattered tree on farmland in the Western zone of Tigray, Northern Ethiopia

\begin{tabular}{|c|c|c|c|c|c|}
\hline \multirow[t]{2}{*}{ Characteristics } & \multicolumn{5}{|l|}{ Elevation (m a.s.l) } \\
\hline & $2500-3000$ & $2000-2500$ & $1000-1500$ & $1500-1000$ & $1000-500$ \\
\hline Slope (Min-Max \%) & $2-30$ & $2-30$ & $0-30$ & $0-30$ & $0-30$ \\
\hline Farming system & Mixed & Mixed & Mixed & Mixed & Mixed \\
\hline Major crop type & $\begin{array}{l}\text { Wheat (Triticum } \\
\text { aestivum), Barley } \\
\text { (Hordeum vulgare), } \\
\text { Teff (Eragrostis tef) }\end{array}$ & $\begin{array}{l}\text { Wheat (Triticum } \\
\text { aestivum), Barley } \\
\text { (Hordeum vulgare), } \\
\text { Teff (Eragrostis tef) }\end{array}$ & $\begin{array}{l}\text { Sesame (Sesamum } \\
\text { indicum), sorghum } \\
\text { (Sorghum bicolor) }\end{array}$ & $\begin{array}{l}\text { Sesame (Sesamum } \\
\text { indicum), sorghum } \\
\text { (Sorghum bicolor), } \\
\text { cotton (Gossypium) }\end{array}$ & $\begin{array}{l}\text { Sesame (Sesamum } \\
\text { indicum), sorghum } \\
\text { (Sorghum bicolor), } \\
\text { cotton (Gossypium) }\end{array}$ \\
\hline Annual temp (Min-Max). & $5.90-22.53{ }^{\circ} \mathrm{C}$ & $11.63-30.16^{\circ} \mathrm{C}$ & $17.78-32.31{ }^{\circ} \mathrm{C}$ & $22.32-35.27^{\circ} \mathrm{C}$ & $25.05-42.52^{\circ} \mathrm{C}$ \\
\hline Annual rainfall & $2316 \mathrm{~mm}$ & 1380 mm & $653 \mathrm{~mm}$ & 615 mm & $609 \mathrm{~mm}$ \\
\hline Major soil type & Nitosol and Leptosol & $\begin{array}{l}\text { Nitosol, Leptosol } \\
\text { and Luvisols }\end{array}$ & $\begin{array}{l}\text { Leptosol and } \\
\text { Luvisols }\end{array}$ & Leptosol and Luvisols & $\begin{array}{l}\text { Vertisol, Cambisol } \\
\text { and Luvisols }\end{array}$ \\
\hline $\begin{array}{l}\text { Dominant trees and/or } \\
\text { shrubs species }\end{array}$ & $\begin{array}{l}\text { Acacia abyssinica } \\
\text { subsp. abyssinica, } \\
\text { Maytenus arbutifolia } \\
\text { and Eucalyptus } \\
\text { camaldulensis }\end{array}$ & $\begin{array}{l}\text { Cordia africana, } \\
\text { Ficus sycomorus } \\
\text { and Croton } \\
\text { macrostachyus }\end{array}$ & $\begin{array}{l}\text { Diospyros mespiliformis, } \\
\text { Anogeissus leiocarpus } \\
\text { and Acacia bussei }\end{array}$ & $\begin{array}{l}\text { Boswellia papyrifera, } \\
\text { Balanites aegyptiaca } \\
\text { and Dalbergia melanoxylon }\end{array}$ & $\begin{array}{l}\text { Pterocarpus leucens, } \\
\text { Ziziphus spinachristi } \\
\text { and Combretum sp. }\end{array}$ \\
\hline
\end{tabular}


by Eq. 1 (Kuyah et al. 2012a) was used to estimate the aboveground biomass (stem plus bark, branches, and foliage) of the trees and/or shrubs. This equation was selected as it was appropriate to estimate a wide range of parameters ranging from $\mathrm{DBH}$ or height to aboveground biomass (Kuyah et al. 2012a) with the lowest prediction error value. Moreover, this equation is developed for trees grown in agroforestry and $\mathrm{DBH}$ greater than $2.5 \mathrm{~cm}$. Besides, this equation was developed in areas having similar environmental conditions (climate and soils) in the study area.

$$
\mathrm{AGB}=0.0905 * \mathrm{DBH}^{2.4718} ; \mathrm{R}^{2}=0.98, n=72
$$

Where AGB is the estimation of the aboveground biomass (kg dry matter/plant) and $\mathrm{DBH}$ is the diameter $(\mathrm{cm})$ at breast height $(1.3 \mathrm{~m})$.

Species-specific allometric equations were also used for estimating above-ground biomasses for trees and shrubs on farmland (Table 2). Then the tree biomass was converted into carbon by using Eq. 2 (MacDicken 1997; Brown 2002).

$$
\mathrm{AGC} \text { or } \mathrm{BGC}=\mathrm{AGB} \text { or } \mathrm{BGB} * 0.5
$$

\section{Belowground carbon stock estimation}

Belowground biomass was estimated following Eq. 3 developed by Kuyah et al. (2012b). This equation was selected for its easiness to apply, less time consuming, and is non-destructive. It estimates belowground biomass carbon (BGC) through a relationship to aboveground biomass. The belowground biomass was estimated following Eq. 3.

$$
\mathrm{BGB}=0.490 * \mathrm{AGB}^{0.923} ; \mathrm{R}^{2}=0.95, n=72
$$

Where $\mathrm{BGB}$ is belowground biomass and $\mathrm{AGB}$ is aboveground biomass.

\section{Soil organic carbon stock estimation}

Soil organic carbon stock (SOC) was estimated following Eq. 4 developed by Pearson et al. (2007). SOC was determined following the Walkley-Black oxidation method (Chesworth 2008). Bulk density was determined using the gravimetric method (Grossman and Reinsch 2002). Samples were then sieved with $2 \mathrm{~mm}$ mesh size sieve and the coarse fragments $(>2 \mathrm{~mm}$ ) weighed. Cumulative subsamples were used for estimation of gravimetric water content and bulk density. Finally, soil carbon stock $\left(\mathrm{Mg} \mathrm{C} \mathrm{ha}{ }^{-1}\right)$ for each sample plot was calculated using Eq. 4:

$$
\operatorname{SOC}\left(\mathrm{MgC} \mathrm{ha}^{-1}\right)=\left(\frac{C}{100}\right) * \rho * d *\left(1-\frac{\text { frag }}{100}\right) * 100
$$

Where $C$ is the soil organic carbon concentration determined in laboratory $\left(\mathrm{g} \mathrm{kg}^{1}\right), \rho$ is the bulk density $\left(\mathrm{g} \mathrm{cm}^{-3}\right), d$ is the soil depth of sampled soil layer $(\mathrm{cm})$, and frag is \% volume of coarse fragments/100.

\section{Total carbon stock estimate}

Total carbon stock was calculated by summing up of the individual carbon pools following Eq. 5 (Pearson et al. 2005). Carbon stock density of the study area:

$$
\mathrm{TC}=\mathrm{AGC}+\mathrm{BGC}+\mathrm{SOC}
$$

Where TC is total carbon, AGC is aboveground carbon, BGC is belowground carbon, and SOC is soil organic carbon.

\section{Statistical analysis}

Data collected from field inventory was organized and recorded in Microsoft Excel 2016 data sheet. The estimated AGB, AGC, BGB, and BGC data were subjected to $\log$ transformation $[\log (n)]$ before statistical analysis to meet the assumption of normal distribution. Both vegetation and soil data were analyzed using univariate analysis. Variables were compared using one-way analysis of variance (ANOVA) at $P<0.05$ with the help of the $\mathrm{R}$ software for Window versions 3.4.3. Whenever statistical difference existed, it was subjected to Tukey's HSD test to separate the means.

\section{Results}

\section{Biomass carbon stocks}

There was a strong variation in the mean aboveground carbon stock between the tree on farmland (Table 3). The upper altitude (2500-3000 $\mathrm{m}$ a.s.l) of the scattered tree on farmland had higher AGC by $21.63 \%$ as compared to the $2000-2500 \mathrm{~m}$ a.s.l. The observed variation in mean AGC along altitudinal gradients was significant

Table 2 Some of the species on which specific allometric equations were applied in the study

\begin{tabular}{lllll}
\hline No & Scientific name & Allometric equation & $R^{2}$ & Reference \\
\hline 1 & Eucalyptus camaldulensis & $\mathrm{AGB}=0.085(\mathrm{DBH})^{2.471}$ & 0.80 & Kuyah et al. (2013) \\
2 & Mangifera indica & $\mathrm{AGB}=-2.43+0.154 \mathrm{DBH}+0.193 \mathrm{H}$ & 0.96 & Chavan and Rasal (2012) \\
3 & Acacia abyssinica & $\mathrm{AGB}=-3.514+2.827 \mathrm{lnDSH}$ & 0.98 & Giday et al. (2013) \\
4 & Balanites aegyptiaca and Acacia seyal & $\mathrm{AGB}=1.929 \mathrm{DBH}+0.116(\mathrm{DBH})^{2}+0.013(\mathrm{DBH})^{3}$ & 0.93 & Mbow et al. (2014) \\
\hline
\end{tabular}


Table 3 Mean ( \pm standard error; $n=15)$ biomass $\left(\mathrm{Mg} \mathrm{ha}^{-1}\right)$, biomass carbon, soil carbon (SOC), and total carbon (total biomass plus SOC 0-60 cm) carbon stocks ( $\mathrm{Mg} \mathrm{C} \mathrm{ha}^{-1}$ ) for each of the five altitudinal gradient class and results of one-way ANOVA (at $a=0.05$, significant differences between altitudinal gradient for any of the C stocks were indicated)

\begin{tabular}{|c|c|c|c|c|c|c|c|}
\hline \multirow{2}{*}{$\begin{array}{l}\text { Biomass and } \\
\text { carbon pools }\end{array}$} & \multicolumn{7}{|c|}{ Altitude (m a.s.l) } \\
\hline & $2500-3000$ & $2000-2500$ & $1500-2000$ & $1000-1500$ & $500-1000$ & Mean & $\operatorname{Pr}(>F)$ \\
\hline$\overline{A G B^{a}}$ & $35.93(7.9)^{a}$ & $7.77(1.7)^{\mathrm{b}}$ & $17.65(3.4)^{\mathrm{ab}}$ & $8.53(1.2)^{b}$ & $9.10(0.9)^{b}$ & 15.80 & $* * *$ \\
\hline$B G B^{b}$ & $13.07(2.7)^{\mathrm{a}}$ & $3.19(0.6)^{b}$ & $6.79(1.2)^{\mathrm{ab}}$ & $3.51(0.4)^{b}$ & $3.75(0.3)^{b}$ & 6.06 & $* * *$ \\
\hline AGC & $17.97(3.9)^{\mathrm{a}}$ & $3.89(0.8)^{b}$ & $8.82(1.7)^{\mathrm{ab}}$ & $4.26(0.6)^{b}$ & $4.55(0.5)^{b}$ & 7.90 & $* * *$ \\
\hline BGC & $6.53(1.08)^{a}$ & $1.59(0.23)^{b}$ & $3.39(0.46)^{\mathrm{ab}}$ & $1.76(0.16)^{b}$ & $1.87(0.12)^{b}$ & 3.03 & $* * *$ \\
\hline $\mathrm{sOC}^{\mathrm{C}} 0-60 \mathrm{~cm}$ & $23.09(1.82)^{a}$ & $21.53(1.72)^{a}$ & $22.55(2.40)^{a}$ & $10.91(0.85)^{b}$ & $22.28(0.83)^{a}$ & 20.07 & $* * *$ \\
\hline Total carbon & $47.59(4.77)^{\mathrm{a}}$ & $27.01(2.49)^{b c}$ & $34.76(3.75)^{b}$ & $16.93(1.16)^{c}$ & $28.71(1.83)^{b c}$ & 31.00 & $* * *$ \\
\hline
\end{tabular}

${ }^{a}$ Trees and shrubs

bStumps, coarse roots, and fine root

'Dead and decay organic matter

$(F=6.1504, p<0.001)$. The pattern of variation in belowground carbon (BGC) among altitudinal ranges was similar to that of AGC for scattered trees on farmland (Table 3; Fig. 2). The highest BGC was found in the 2500-3000 m altitudinal class (6.53 $\mathrm{Mg} \mathrm{C} \mathrm{ha}^{-1}$ ) followed by $1500-2000 \mathrm{~m}$ altitudinal class $\left(3.39 \mathrm{Mg} \mathrm{C} \mathrm{ha}^{-1}\right)$. The variation of $\mathrm{BGC}$ of the scattered tree on farmland along the altitudinal gradient was statistically significant $(F=6.1168, P<0.001)$.

\section{Soil organic carbon stocks}

The mean SOC stocks by the altitudinal gradient of the scattered tree on farmland were variable (Table 3; Fig. 2). Similar to biomass carbon stocks, mean SOC stocks were the highest for the 2500-3000 m a.s.l (47.59 $\mathrm{Mg} \mathrm{C} \mathrm{ha}{ }^{-1}$ ) and the lowest for the 1000$1500 \mathrm{~m}$ a.s.l $\left(10.91 \mathrm{Mg} \mathrm{C} \mathrm{ha}{ }^{-1}\right)$. However, similar to our hypothesis, the differences between altitudinal gradient mean SOC stock values were great and significantly different $(F=8.234, P<0.001)$ (Table 3$)$.

\section{Total carbon stocks}

The proportion of total biomass carbon to the total carbon stock was averaged 35\% for all altitudinal gradient. We hypothesized that carbon stocks would significantly differ between altitudinal gradient, and the differences were found to be significant (Table 3). However, biomass carbon stocks were dominated $(>50 \%)$ by tree biomass. Mean carbon stocks did significantly differ between the altitudinal gradient $(F=10.225, P<0.001)$, as we had hypothesized. The highest total carbon stock density scores in 2500-3000 $\mathrm{m}$ a.s.l $\left(47.59 \mathrm{Mg} \mathrm{C} \mathrm{ha}^{-1}\right)$ and the lowest in the $1000-1500 \mathrm{~m}$ a.s.l $\left(16.93 \mathrm{Mg} \mathrm{C}^{-1}\right)$.

\section{Discussions}

\section{Biomass carbon stocks}

Biomass carbon stock of scattered tree on farmland showed that there is significant variation along an altitudinal gradient. Our result contradicts with the findings from Leuschner et al. (2007) and Zhu et al. (2010) who reported that above- and belowground tree biomass and its carbon stock

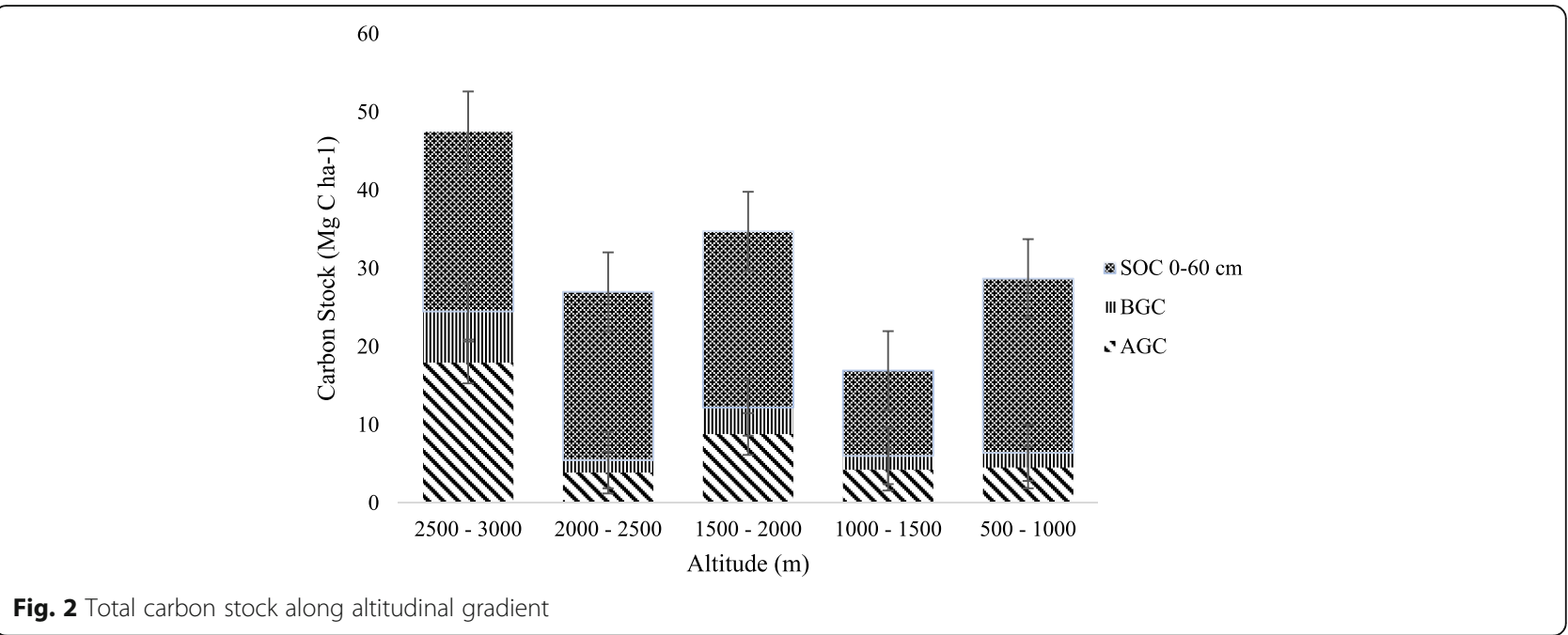


decline with an increase in altitude. The increasing biomass carbon with altitude in the current study may be attributed to disturbance and diameter class distribution. The lower altitudinal gradient of the study area is highly influenced by the local people through cultivable land expansion and procuring essential forest products which is probably the cause for the lower biomass at lower elevations. On the other hand, the presence of species characterized by large individuals and also posibly due to the favorable conditions for tree growth in the upper altitude, because few large individuals can account for the large amount of above and below ground carbon (Rahayu et al. 2005). This is probably the case in the present study area, where bigger trees with maximum DBH were more frequent at higher altitudes.

Total biomass carbon ranges from 1.07 to $209.41 \mathrm{Mg}$ C $\mathrm{ha}^{-1}$ among altitudinal gradients. Therefore, this result was within the range reported at a global scale. Agroforestry system stores 12 to $228 \mathrm{Mg} \mathrm{C} \mathrm{ha}{ }^{-1}$ (Dixon 1995), deciduous forests and savannas in Brazil also store 6$24 \mathrm{Mg} \mathrm{c} \mathrm{ha}^{-1}$ (Silva et al. 2013), for trees used in the various systems Sub-Saharan Africa stores 7-28 Mg C ha ${ }^{-1}$ (Unruh et al. 1993), and for the humid tropical Africa for Agrosilvicutural agroforestry System stores 29-53 $\mathrm{Mg} \mathrm{C}$ ha $^{-1}$ (Albrecht and Kandji 2003). However, biomass carbon stock values were lower than reported for traditional agroforestry systems in the tropics reported $145 \mathrm{Mg} \mathrm{C} \mathrm{ha}{ }^{-1}$ (Kirby and Potvin 2007), smallholder agroforestry system in the tropics which ranges 228-246 $\mathrm{Mg} \mathrm{C} \mathrm{ha}^{-1}$ (Roshetko et al. 2007), and smallholder cacao (Theobroma cacao Linn.) based agroforestry systems in western and central Africa stores 152.2 $\mathrm{Mg} \mathrm{C} \mathrm{ha}^{-1}$ (Duguma et al. 2001).

\section{Soil organic carbon stocks}

SOC plays a vital role in the global carbon cycle, forming large carbon pools with long residence times (Post et al. 1982). The SOC stocks scattered trees on the farm of the study area ranged between 2.28 and $40.5 \mathrm{Mg} \mathrm{C} \mathrm{ha}^{-1}$ are noticeably lower compared to the SOC stocks of other ecosystems and soils. The SOC stock at $60 \mathrm{~cm}$ layer for tropical forest, tropical savannah, and tropical agricultural land has been reported to be $121-123 \mathrm{Mg} \mathrm{C}$ $\mathrm{ha}^{-1}, 110-117 \mathrm{MgC} \mathrm{ha}^{-1}$, and 80-103 $\mathrm{MgC} \mathrm{ha}^{-1}$ respectively (Lal 2004), for agroforestry-based crop production of semi-arid areas of Northern Ethiopia stores $25.8 \mathrm{Mg} \mathrm{C} \mathrm{ha}^{-1}$ (Gelaw et al. 2014), for semi-arid Acacia woodland in southern Ethiopia stores $42.9 \mathrm{Mg} \mathrm{C} \mathrm{ha}{ }^{-1}$ (Lemenih and Itanna 2004), and for agrisilviculture agroforestry systems of India stores 27.4 $\mathrm{Mg} \mathrm{C} \mathrm{ha}^{-1}$ (Swamy and Puri 2005) and for tropical soils estimates $86 \mathrm{Mg} \mathrm{C}$ $\mathrm{ha}^{-1}$ (Brown and Lugo 1982). But, significantly higher than the rainfed crop production of semi-arid areas in Northern Ethiopia stores $16.1 \mathrm{Mg} \mathrm{C}^{-1}$ (Gelaw et al. 2014). SOC stocks of the study area were also within the ranges of those reported for cultivated and grazing land of East and West Africa 18.5-52.5 $\mathrm{Mg} \mathrm{C} \mathrm{ha}^{-1}$ and 22.454.0 Mg C ha ${ }^{-1}$ respectively (Brown et al. 2012), and for traditional agroforestry practiced in southern Ethiopia ranges 28.2-98.9 $\mathrm{Mg} \mathrm{ha}^{-1}$ (Demessie et al. 2013).

SOC stocks in the soils studied showed significant variations with altitude. This could be due to more or less difference in vegetation structure and diversity through all elevation gradient, which may accumulate the different amount of organic matter due to high inputs from root biomass and aboveground. Various studies indicate that soil carbon stocks increase with elevation in mountainous areas (Bolstad et al. 2001). It can also be attributed to the soils in cooler climates usually contain more organic matter due to slower mineralization rates and soil organic matter (SOM) accumulation increases with increasing precipitation. Differences along vegetation gradients reflect a changing balance of soil carbon inputs and soil carbon losses that are related to changes in both abiotic (temperature, precipitation, potential evapotranspiration) and biotic (litter quality) factors (Lal 2004; Garten and Hanson 2006). The low levels of SOC in the 1000-1500 m a.s.l altitudinal gradient imply an effect on soil physical and chemical characteristics, soil fertility status, and biological activities (Weil and Brady 2002). Therefore, a low level of SOC in 1000-1500 m a.s.l affects crop productivity when we compare with the other altitudinal gradient class. Cultivated area management such as crop residue retention and crop rotation contribute to improving SOC stocks (Raffa et al. 2015), and these strategies could be utilized in the 1000-1500 m a.s.l altitudinal areas to enhance crop productivity.

\section{Total carbon stocks}

The distribution of carbon stocks between biomass and soil differs among ecosystems and varies with an altitudinal gradient. The total carbon stocks (biomass carbon + soil carbon) of the study area scattered trees on farmland (2.67-89.62 $\mathrm{Mg} \mathrm{C} \mathrm{ha}^{-1}$ and averaging $31 \mathrm{MgC}$ $\mathrm{ha}^{-1}$ ) were within the range to that of tropical agroforestry 7.9-105 Mg C ha ${ }^{-1}$ (Montagnini and Nair 2004), traditional agroforestry system of humid sub tropical ranges 10.29-31.86 $\mathrm{Mg} \mathrm{C} \mathrm{ha}{ }^{-1}$ (Yadava 2010), and Cocoa-based agroforestry practiced in Nigeria that ranged 16-96.01 $\mathrm{Mg} \mathrm{C} \mathrm{ha}^{-1}$ (Oke and Olatiilu 2011). The difference in carbon stock could be attributed due to farm size, management, socio-economic needs, species diversity, the age of trees, local climate, and tree spacing among agroforestry system (Kumar 2011) and higher levels of disturbance (pruning and damage), intensive management practices, and small land size that forces scattered trees on farmland not only having a higher density of wood perennials but also an accumulation of other plants and crops per unit area. 


\section{Conclusions}

The scattered trees on the farmland of the semi-arid area of western Tigray in Ethiopia are not only for crop production and soil and water conservation but also contributed to adapt the changing climate by providing provisioning, supporting and regulating services. However, there is a total of $31 \mathrm{MgC} \mathrm{ha}{ }^{-1}$, which suggests that the significant potential of these production systems to store and enhance ecosystem carbon stocks. This could be an attractive opportunity for farmers to benefit economically from scattered trees on farmland if the carbon sequestered is sold to developed countries. The total carbon produced from the upper altitudinal gradient is higher than that of other altitudinal gradient class, highlighting that the elevation gradient can actively influence carbon stock accumulation on farmland. Biomass carbon stocks were significantly less than the SOC stocks in almost all altitudinal gradient class. Scattered trees on farmland in the study area were large potential in carbon sinks. However, illegal exploitations and unmanaged grazing have threatened the system. Hence, this calls for an integrated action to control the problem.

\section{Acknowledgements}

The authors acknowledge the financial support from Tigray Agricultural Research Institute (Humera Agricultural Research Center) and technical support from Mekelle University. We are grateful to the two anonymous referees for constructive comments on an earlier version of this manuscript.

\section{Funding}

The funders had no role in study design, data collection and analysis, decision to publish, or preparation of the manuscript.

\section{Availability of data and materials}

Please contact author for data requests.

\section{Authors' contributions}

$Y G, T G$, and $E B$ designed the study. YG conducted the laboratory experiment. $Y G$ and $E B$ analyzed the data. $Y G, T G, K T$, and EB wrote the manuscript. All authors read and approved the final manuscript.

Ethics approval and consent to participate

Not applicable.

\section{Consent for publication}

Not applicable.

\section{Competing interests}

The authors declare that they have no competing interests.

\section{Publisher's Note}

Springer Nature remains neutral with regard to jurisdictional claims in published maps and institutional affiliations.

\footnotetext{
Author details

${ }^{1}$ Humera Agricultural Research Center (HuARC), Tigray Agricultural Research Institute (TARI), P.O. Box 62, Humera, Ethiopia. ${ }^{2}$ Department of Land Resources Management and Environmental Protection, Mekelle University, P.O. Box 231, Mekelle, Ethiopia. ${ }^{3}$ Ministry of Environment, Forest and Climate Change of Ethiopia, Addis Ababa, Ethiopia. ${ }^{4}$ Faculty of Environmental Sciences and Natural Resource Management Norwegian University of Life Sciences, PO Box 5003, 1432 Ås, Norway.
}

Received: 31 July 2018 Accepted: 27 November 2018

Published online: 19 December 2018

\section{References}

Albrecht A, Kandji ST (2003) Carbon sequestration in tropical agroforestry systems. Agric Ecosyst Environ 99(1-3):15-27. https://doi.org/10.1016/S01678809(03)00138-5

Barrios E, Sileshi GW, Shepherd K, Sinclair F (2012) Agroforestry and soil health: linking trees, soil biota, and ecosystem services. In: Wall DH et al (eds) Soil ecology and ecosystem services. Oxford University Press, Oxford, pp 315-330

Bein E, Habte B, Jaber A, Birnie A, Tengnäs B (1996) Useful trees and shrubs in Eritrea: identification, propagation, and management for agricultural and pastoral communities. In: Technical handbook(12), vol 422. ICRAF Project, World Agroforestry Centre, Eastern Africa Region, Nirobi

Bekele-Tesemma A, Tengnäs B (2007) Useful trees and shrubs of Ethiopia: identification, propagation, and management for 17 agroclimatic zones. RELMA in ICRAF Project, World Agroforestry Centre, Eastern Africa Region

Bolstad PV, Vose JM, McNulty SG (2001) Forest productivity, leaf area, and terrain in southern Appalachian deciduous forests. For Sci 47(3):419-427

Boye A, Albrecht A (2005) Soil erodibility control and soil carbon losses under short term tree fallows in western Kenya. Advances in Soil Science

Brown S (2002) Measuring carbon in forests: current status and future challenges. Environ Pollut 116(3):363-372. https://doi.org/10.1016/S0269-7491(01)00212-3

Brown S, Grais A, Ambagis S, Pearson T (2012) Baseline GHG emissions from the agricultural sector and mitigation potential in countries of East and West Africa. CCAFS Working Paper 13. Copenhagen, Denmark: CCAFS https://ccafs. cgiar.org/publications/baseline-ghg-emissions-agricultural-sector-andmitigation-potential-countries-east-and\#.XAYmG-9LHoE. Accessed 13 Mar 2018.

Brown S, Lugo AE (1982) The storage and production of organic matter in tropical forests and their role in the global carbon cycle. Biotropica:161-187. https://doi.org/10.2307/2388024

Bunker DE, DeClerck F, Bradford JC, Colwell RK, Perfecto I, Phillips OL, Naeem S (2005) Species loss and aboveground carbon storage in a tropical forest. Science 310(5750):1029-1031. https://doi.org/10.1126/science.1117682

Chavan B, Rasal G (2012) Total sequestered carbon stock of Mangifera indica. J Environ Earth Sci 2(1)

Chesworth W (2008) Encyclopedia of soil science, 1st edn. Springer: Netherland

Demessie A, Singh BR, Lal R (2013) Soil carbon and nitrogen stocks under chronosequence of farm and traditional agroforestry land uses in Gambo District, southern Ethiopia. Nutr Cycl Agroecosyst 95(3):365-375. https://doi. org/10.1007/s10705-013-9570-0

Dixon R (1995) Agroforestry systems: sources of sinks of greenhouse gases? Agrofor Syst 31(2):99-116. https://doi.org/10.1007/BF00711719

Duguma B, Gockowski J, Bakala J (2001) Smallholder cacao (Theobroma cacao Linn.) cultivation in agroforestry systems of West and Central Africa: challenges and opportunities. Agrofor Syst 51(3):177-188. https://doi.org/10. 1023/A:1010747224249

Garten CT, Hanson PJ (2006) Measured forest soil C stocks and estimated turnover times along an elevation gradient. Geoderma 136(1-2):342-352. https://doi.org/10.1016/j.geoderma.2006.03.049

Gelaw AM, Singh B, Lal R (2014) Soil organic carbon and total nitrogen stocks under different land uses in a semi-arid watershed in Tigray, northern Ethiopia. Agric Ecosyst Environ 188:256-263. https://doi.org/10. 1016/j.agee.2014.02.035

Giday K, Eshete G, Barklund P, Aertsen W, Muys B (2013) Wood biomass functions for Acacia abyssinica trees and shrubs and implications for provision of ecosystem services in a community managed exclosure in Tigray, Ethiopia. J Arid Environ 94:80-86. https://doi.org/10.1016/j.jaridenv.2013.03.001

Grossman R, Reinsch T (2002) 2.1 Bulk density and linear extensibility. Methods of soil analysis: part 4 physical methods(methodsofsoilan4), pp 201-228

Hairiah K, Sitompul S, van Noordwijk M, Palm C (2001) Methods for sampling carbon stocks above and below ground. ICRAF Bogor, Indonesia

Henry M, Tittonell P, Manlay RJ, Bernoux M, Albrecht A, Vanlauwe B (2009) Biodiversity, carbon stocks and sequestration potential in aboveground biomass in smallholder farming systems of western Kenya. Agric Ecosyst Environ 129:238-252. https://doi.org/10.1016/j.agee.2008.09.006

Hurni H (1998) Agroecological belts of Ethiopia. Switzerland: Center for development and environment univeristy of Bern, Switzerland in association with the ministry of agriculture, Ethiopia 
Kirby KR, Potvin C (2007) Variation in carbon storage among tree species: implications for the management of a small-scale carbon sink project. For Ecol Manag 246(2-3):208-221. https://doi.org/10.1016/j.foreco.2007.03.072

Körner C (2007) The use of altitude in ecological research. Trends Ecol Evol 22(11):569-574

Kumar BM (2011) Species richness and aboveground carbon stocks in the homegardens of central Kerala, India. Agric Ecosyst Environ 140(3-4):430440. https://doi.org/10.1016/j.agee.2011.01.006

Kuyah S, Dietz J, Muthuri C, Jamnadass R, Mwangi P, Coe R, Neufeldt H (2012a) Allometric equations for estimating biomass in agricultural landscapes: I. aboveground biomass. Agric Ecosyst Environ 158:216-224. https://doi.org/10. 1016/j.agee.2012.05.011

Kuyah S, Dietz J, Muthuri C, Jamnadass R, Mwangi P, Coe R, Neufeldt H (2012b) Allometric equations for estimating biomass in agricultural landscapes: II. belowground biomass. Agric Ecosyst Environ 158:225-234. https://doi.org/10. 1016/j.agee.2012.05.010

Kuyah S, Dietz J, Muthuri C, van Noordwijk M, Neufeldt H (2013) Allometry and partitioning of above- and below-ground biomass in farmed eucalyptus species dominant in Western Kenyan agricultural landscapes. Biomass Bioenergy 55:276-284. https://doi.org/10.1016/j.biombioe.2013.02.011

Kuyah S, Öborn I, Jonsson M, Dahlin AS, Barrios E, Muthuri C, Namirembe S (2016) Trees in agricultural landscapes enhance provision of ecosystem services in sub-Saharan Africa. Int J Biodiversity Sci Ecosyst Ser Manage 12(4): 255-273. https://doi.org/10.1080/21513732.2016.1214178

Lal R (2004) Soil carbon sequestration to mitigate climate change. Geoderma 123(1-2):1-22. https://doi.org/10.1016/j.geoderma.2004.01.032

Lemenih M, Itanna F (2004) Soil carbon stocks and turnovers in various vegetation types and arable lands along an elevation gradient in southern Ethiopia. Geoderma 123(1-2):177-188. https://doi.org/10.1016/j.geoderma.2004.02.004

Leuschner C, Moser G, Bertsch C, Röderstein M, Hertel D (2007) Large altitudinal increase in tree root/shoot ratio in tropical mountain forests of Ecuador. Basic and Applied Ecology 8(3):219-230. https://doi.org/10.1016/j.baae.2006.02.004

MacDicken KG (1997) A guide to monitoring carbon storage in forestry and agroforestry projects. Winrock International Institute for Agricultural Development

Mbow C, Smith P, Skole D, Duguma L, Bustamante M (2014) Achieving mitigation and adaptation to climate change through sustainable agroforestry practices in Africa. Curr Opin Environ Sustain 6:8-14. https://doi. org/10.1016/j.cosust.2013.09.002

Montagnini F, Nair P (2004) Carbon sequestration: an underexploited environmental benefit of agroforestry systems New vistas in agroforestry. Springer, pp 281-295. https://doi.org/10.1007/978-94-017-2424-1_20

Negash M, Starr M (2015) Biomass and soil carbon stocks of indigenous agroforestry systems on the south-eastern Rift Valley escarpment, Ethiopia. Plant Soil 393(1-2):95-107. https://doi.org/10.1007/s11104-015-2469-6

Newaj R, Chaturvedi O, Handa A (2016) Recent development in agroforestry research and its role in climate change adaptation and mitigation. Indian $\mathrm{J}$ of Agroforestry Vol 18(1):1-9

Nikiema A (2005) Agroforestry parkland species diversity: uses and management in semi-arid West-Africa (Burkina Faso). Ph.D. Dessertation. Wageningen University, Wageningen

Nyaga J, Barrios E, Muthuri C, Öborn I, Matiru V, Sinclair F (2015) Evaluating factors influencing heterogeneity in agroforestry adoption and practices within smallholder farms in Rift Valley, Kenya. Agric Ecosyst Environ 212:106118. https://doi.org/10.1016/j.agee.2015.06.013

Oke D, Olatiilu A (2011) Carbon storage in agroecosystems: a case study of the cocoa based agroforestry in Ogbese Forest reserve, Ekiti state, Nigeria. J Environ Prot 02(08):1069-1075. https://doi.org/10.4236/jep.2011.28123

Pearson T, Walker S, Brown S (2005) Sourcebook for land use, land-use change, and forestry projects, vol 57. Winrock International and the BioCarbon Fund of the World Bank

Pearson TR, Brown SL, Birdsey RA (2007) Measurement guidelines for the sequestration of forest carbon. US Department of Agriculture, Forest Service, Northern Research Station

Ponce-Hernandez R, Koohafkan P, Antoine J (2004) Assessing carbon stocks and modelling win-win scenarios of carbon sequestration through land-use changes, vol 1. Food \& Agriculture Org

Post WM, Emanuel WR, Zinke PJ, Stangenberger AG (1982) Soil carbon pools and world life zones. Nature 298(5870):156. https://doi.org/10.1038/298156a0

Raffa DW, Bogdanski A, Tittonell P (2015) How does crop residue removal affect soil organic carbon and yield? A hierarchical analysis of management and environmental factors. Biomass Bioenergy 81:345-355. https://doi.org/10. 1016/j.biombioe.2015.07.022

Rahayu S, Lusiana B, Van Noordwijk M (2005) Above ground carbon stock assessment for various land use systems in Nunukan, East Kalimantan. Carbon Stock Monitoring in Nunukan, East Kalimantan: A Spatial and Modelling Approach. World Agroforestry Centre, SE Asia, Bogor, pp 21-34

Roshetko JM, Delaney M, Hairiah K, Purnomosidhi P (2002) Carbon stocks in Indonesian homegarden systems: can smallholder systems be targeted for increased carbon storage? Am J Altern Agric 17(3):138-148. https://doi.org/ 10.1079/AJAA200116

Roshetko JM, Lasco RD, Angeles MSD (2007) Smallholder agroforestry systems for carbon storage. Mitig Adapt Strateg Glob Chang 12(2):219-242. https://doi. org/10.1007/s11027-005-9010-9

Scherr SJ, McNeely JA (2008) Biodiversity conservation and agricultural sustainability: towards a new paradigm of 'ecoagriculture' landscapes. Philosophical Transactions of the Royal Society B: Biological Sciences 363(1491):477-494. https://doi.org/10.1098/rstb.2007.2165

Silva LC, Hoffmann WA, Rossatto DR, Haridasan M, Franco AC, Horwath WR (2013) Can savannas become forests? A coupled analysis of nutrient stocks and fire thresholds in central Brazil. Plant Soil 373(1-2):829-842. https://doi.org/10. 1007/s11104-013-1822-x

Swamy S, Puri S (2005) Biomass production and C-sequestration of Gmelina arborea in plantation and agroforestry system in India. Agrofor Syst 64(3): 181-195. https://doi.org/10.1007/s10457-004-1999-3

Teklay T (2005) Organic inputs from agroforestry trees on farms for improving soil quality and crop productivity in Ethiopia. Ph.D. Dessertation. Swedish University of Agricultural Sciences

Unruh J, Houghton R, Lefebvre P (1993) Carbon storage in agroforestry: an estimate for sub-Saharan Africa. Clim Res:39-52. https://doi.org/10.3354/cr003039

Weil RR, Brady N (2002) The nature and properties of soil. Pearson Education Ltd 5:359-387

Yadava AK (2010) Carbon sequestration: underexploited environmental benefits of Tarai agroforestry systems. Report and opinion 2(11):35-41. https://doi.org/ 10.7537/marsroj021110.07

Young A (1997) Agroforestry for soil management. CAB international

Zhu B, Wang X, Fang J, Piao S, Shen H, Zhao S, Peng C (2010) Altitudinal changes in carbon storage of temperate forests on Mt Changbai, Northeast China. J Plant Res 123(4):439-452. https://doi.org/10.1007/s10265-009-0301-1

Zomer RJ, Trabucco A, Coe R, Place F (2009) Trees on farm: analysis of global extent and geographical patterns of agroforestry, vol 89. ICRAF Working Paper-World Agroforestry Centre. http://www.worldagroforestry.org/ downloads/Publications/PDFS/WP14064.pdf

\section{Submit your manuscript to a SpringerOpen ${ }^{\circ}$ journal and benefit from:}

- Convenient online submission

- Rigorous peer review

- Open access: articles freely available online

High visibility within the field

- Retaining the copyright to your article

Submit your next manuscript at $>$ springeropen.com 